\title{
GROWTH OF THREE TIMBER TREES AS AFFECTED BY AMOUNTS OF WASTEWATER APPLICATION AND IRRIGATION SYSTEMS
}

(Received: 5.12.2018)

\author{
By \\ H. H. Hamad , M. H. Khamis and M. I. Bahnasy \\ Forestry and timber Trees Department, Horticultural Research Institute, Agriculture Research \\ Center, Giza, Egypt.
}

\begin{abstract}
Five-year-old Gmelina arborea, Khaya senegalensis and Tectona grandis seedlings were investigated at Sarabium Plantation, located in North Eastern Egypt, allocated for wastewater disposal. The study monitored the growth, above ground biomass, water use efficiency, nutrients and heavy metals content of these species throughout three seasons (2016, 2017 and 2018). The study was laid out on a randomized complete block design in split plot layout with three replications. There were 12 treatments including three irrigation treatments (A1) approximately $130 \%$; (A2) $100 \%$; and (A3) 70 $\%$ of evapotranspiration. These amounts of water was applied as main plot and four types of micro irrigation systems: bubblers (Bub.), on line dripper (Drip.), built-in dripper (G.R.) and sub-surface drip irrigation (SSD), as sub-plot factor. The results showed that using bubblers system together with the application of 10.31 tree $^{-1} \mathrm{day}^{-1}$ of wastewater could be recommended in Sarabium area where water is not a limiting factor to provide the highest growth parameters and biomass production of Gmelina arborea, Khaya senegalensis and Tectona grandis tree species. Also, values of water use efficiency indicated that $0.76,1.01,1.33$ and $2.4 \mathrm{~m}^{3}$ of water were needed to produce one kilogram of dry matter yield using Bub., Drip., G.R., and SSD in Gmelina arborea; 0.59, 0.74, 0.97, and $2.0 \mathrm{~m}^{3}$ in Khaya senegalensis and $0.24,0.40,0.57$, and $0.76 \mathrm{~m}^{3}$ in Tectona grandis, respectively. This means that water savings were achieved with the Bub. system in comparing with Drip., G.R. and SSD were 0.25, 57, and $1.64 \mathrm{~m}^{3}$ in Gmelina arborea; $0.15,0.38,1.41 \mathrm{~m}^{3}$ in Khaya senegalensis and $0.16,0.33$ and 0.52 $\mathrm{m}^{3}$ in Tectona grandis, respectively. The results of the present study could contribute in the Egyptian sustainable development strategy 2030, as it achieves the target of "managing the natural resources" through forestation the desert land and reuse the wastewater to produce woody biomass.
\end{abstract}

Keywords: micro-irrigation, timber trees, evapotranspiration, waste water.

\section{INTRODUCTION}

Egypt, as a number of Mediterranean countries, suffers from water scarcity which has become severe in recent years due to global climate change causing frequent and long lasting periods of drought. In the last decades, Egypt has faced the negative impact of drought, and resource scarcity has mostly penalized agricultural activities which use more than $80 \%$ of the total available water. While, other high priority demands such as those from municipal and industrial sectors, are satisfied. Treated municipal wastewater is the most readily available source of water to meet the increasing demand for crop irrigation, especially the tree plantations. Wastewater reuse not only provides significant amounts of irrigation water, but also contributes to conserve potable resources and reduces the environmental impact related to the effluents discharge into water bodies (Aiello $e t$ al., 2007). Soil application of treated wastewater also constitutes a reliable source of nutrients (especially nitrogen, phosphorus and potassium) and organic matter useful for maintaining the fertility and the productivity of the soil (Rusan $e t$ $a l .$, 2007). Treated wastewater should be used for irrigation under controlled conditions, and to minimize hazards from toxic and pathogenic contaminants to agricultural products, soil and groundwater (Aiello et al., 2007). Wastewater may contain a variety of pollutants such as salts, heavy metals, organic compounds, enteric bacteria and viruses. An excessive accumulation of trace elements, such as $\mathrm{Cd}, \mathrm{Cu}, \mathrm{Fe}, \mathrm{Mn}, \mathrm{Pb}$ and $\mathrm{Zn}$ in soils through irrigation creates problems for agricultural production (Singh et 
al., 2004) and leads to metal uptake by crops, affecting food quality and safety (Khan et al., 2008). Egypt offers a great prospect for extensive afforestation due to availability of sufficient wastewater and desert lands. According to a World Bank study, Egypt is the second country that uses the largest volumes of wastewater $\left(1.9\right.$ million $\left.\mathrm{m}^{3} \mathrm{~d}^{-1}\right)$ for irrigation (Scheierling et al., 2010). Also, management conservation for natural resource, as the neglected lands and waste water, is fulfillment of the $15^{\text {th }}$ goal of sustainable development "Protect, restore and promote sustainable use of terrestrial ecosystems, sustainably manage forests, combat desertification, and stop and reverse land degradation" (United Nations 2014). The safe disposal of wastewater as well, is fulfillment the $3^{\text {th }}, 6^{\text {th }}, 11^{\text {th }}$ and $12^{\text {th }}$ goals of sustainable development. The Egyptian code for reuse of treated wastewater for agricultural purposes (ECP 501, 2005) prohibited the usage of raw municipal wastewater for agricultural use, whereas the treated wastewater could be used for afforestation in the desert areas. After basic treatment, wastewater can be efficiently used as a resource for the production of wood and biofuel crops, as well as for carbon trading. The cause of the non-existence of forest in Egypt is not only the climatic conditions and the scarcity of rainfalls, but also the result of focusing on food production for the rapidly increasing population. Egypt's area exceedes over one million square kilometers, where desert land dominates over $96 \%$ of the total land area with little scattered shrub vegetation. Forestation in Egypt is mainly based on plantations with most common tree species, being Casuarina spp. and Eucalyptus spp., which are used as wind breakers. The afforestation efforts aim to plant different species as wood and biofuel resources. The results revealed that sewage water could be used for the establishment of new plantations in desert lands and showed high potential for afforestation of multipurpose species of socioeconomic importance. El Kateb and Mosandl (2012) determined the yield of some tree species of the forest plantations in Egypt, which was high and estimated that the volume achieved in Egypt is approximately attained 4.5 times earlier than in Germany, the leading country in Forestry in Europe. Micro-irrigation, the slow rate of water application at discrete locations at low pressures, includes trickles, subsurface Drip. micro-sprinklers and Bubblers. It has formed enormous advances in last three decades, and became the modern standard for capable irrigation practices for water saving and optimal plant responses (Evans and Sadler 2008). Microirrigation is more flexible set of technologies that could be economically used on almost every crop, soil type and climatic zone, but it requires a high level of management. Micro-irrigation has advantages as well as disadvantages to consider and understand before applying. The advantages include water conservation and reduced deleterious water quality impacts due to high application efficiencies, automation capabilities, improved or increased yields, ease of chemical applications and potential sustainability. The disadvantages include a high possibility for emitter plugging, highly costs, and required high levels of management. The objectives of the present work were to determine the appropriate amount of wastewater, and to identify the suitable irrigation system for growth of Khaya senegalensis, Gmelina arborea and Tectona grandis planted in sandy soil as sources of precious hardwood species at a longer experimental period (3 successive seasons).

\section{MATERIALS AND METHODS 2.1. Site description and weather information}

This study was carried out at Sarabium plantation located in North Eastern Egypt (N $30^{\circ}$ $28^{\prime \prime} 49.14^{\prime}$ E $32^{\circ} 13^{\prime \prime} 29.86^{\prime}$ ) within the Governorate of Ismailia, throughout three seasons (2016, 2017 and 2018). The study area was allocated for wastewater disposal since 2013. The site is about $30 \mathrm{~m}$ above sea level with an annual rainfall of $29 \mathrm{~mm} /$ year. The average of minimum and maximum temperatures was 14.65 and $27.9^{\circ} \mathrm{C}$. The relative humidity recorded $53.9 \%$, and wind speed of 2.5 $\mathrm{m} / \mathrm{s}$. The total annual evapotranspiration (ETo) is $1821 \mathrm{~mm} /$ year (Ismailia Governorate Weather Station). The soil of the experimental site is sandy texture, none saline, and none calcareous. The sand, silt and clay averaged 92.5, 3.28, and $4.22 \%$, respectively. Field capacity and available water were as low as $5.6 \%$ and $4.5 \%$. Moreover, the soil conductivity was $1.07 \mathrm{dS} / \mathrm{m}$ and $\mathrm{pH} 7.03$ measured in (1:2.5) soil: water extract.

\subsection{Experimental procedure and design}

One-year-old tree seedlings of white teak (Gmelina arborea), African mahogany (Khaya senegalensis) and Teak (Tectona grandis) were transplanted in autumn of 2013 at this plantation. The current study monitored the growth and above ground biomass of these species throughout three seasons 2016, 2017 and 2018, 
i.e., after 3, 4, and 5 years from planting, respectively. The plant species were distributed onto three plots. Each plot was $22 \times 53 \mathrm{~m}$, planted with 120 seedlings of one species with distance $2.2 \times 4.4 \mathrm{~m}$. The study was laid out on randomized complete block design in split plot layout with three replications. There were 12 treatments, including three irrigation levels: approximately $130 \%$ (A1), 100\% (A2) and 70\% (A3) of the evapotranspiration. These amounts of water were applied as main plot and four types of micro irrigation systems, namely Bubblers (Bub.), on line dripper (Drip.), built-in dripper (G.R.) and sub-surface drip irrigation (SSD) as sub-plot factor. For measuring the amounts of irrigation water applied, a flow meter was used with each micro irrigation system. The amount of water applied were 10.3, 7.7 and 5.1 1 tree $^{-1}$ day $^{-1}$ for A1, A2 and A3, respectively.

\subsection{Crop water requirement}

Crop water requirement (ETc) was calculated according to the following equation (Allen et al., 1998):

$\mathrm{ETc}=\mathrm{ETo} * \mathrm{Kc}$

Where;

$\mathrm{ETc}=$ Crop Evapotranspiration, $\left(\mathrm{mmday}^{-1}\right)$.

$\mathrm{ETo}=$ Reference Evapotranspiration, $\left(\mathrm{mmday}^{-1}\right)$.

$\mathrm{Kc}=$ Crop coefficients

The reference evapotranspiration was estimated from the agro-climatic data retrieved from the weather station located in the site and the Penman-Monteith method equation (Allen et al., 1998) with FAO crop coefficients for oil seed crops or citrus tree. The total water applied was calculated using effective rainfall ( $\mathrm{mm} /$ day) and the overall irrigation efficiency, which was approximately $95 \%$.

\subsection{Data collection}

Initially, nine individual plants were marked in each treatment. At last week of October of each year however, plant height, number of branches, stem diameter at breast height (DBH) to the nearest millimeter was measured using a caliper, then stem diameters were converted to basal area. Stand Basal Area (SBA) is simply the cross-sectional area of all the trees at breast height per hectare of plantation $\left(\mathrm{m}^{2} \mathrm{ha}^{-1}\right)$ : Stand Basal Area $\left(\mathrm{m}^{2} \mathrm{ha}^{-1}\right)=$ Basal area of tree $\mathrm{x}$ Stocking $\left(\right.$ treeha $\left.^{-1}\right)$. The water use efficiency WUE $\left(\mathrm{kg} \mathrm{m}^{-3}\right)$ was calculated according to the following:

WUE $=$ biomass $\mathrm{kg} /$ water applied $\mathrm{m}^{3}$

In the last week of September 2018 otherwise, three seedlings from each replicate were sampled to measure above ground biomass (main stem, branches, and leaves).

\subsection{Water analysis}

Three samples of wastewater were collected and transported to the laboratory in refrigerated bags. They were then kept in a refrigerator and examined within $24 \mathrm{~h}$ of collection. Chemical analysis of treated wastewater was according to standard methods (APHA-AWWA-EF, 2005)

Table (1): Chemical analysis of the treated wastewater used for irrigation in the current study.

\begin{tabular}{|c|c|c|c|}
\hline Parameter & Value & Parameter & Value \\
\hline TSS mg $1^{-1}$ & 28.6 & Total P mg $~^{-1}$ & 2.89 \\
\hline $\mathrm{pH}$ & 7.68 & $\mathrm{~Pb} \mathrm{ppm}$ & 1.03 \\
\hline $\mathrm{EC} \mathrm{dsm}^{-1}$ & 1.63 & Ni ppm & 0.05 \\
\hline TDS $\mathrm{mg} \mathrm{l}^{-1}$ & 620 & Cd ppm & 0.07 \\
\hline $\mathrm{BOD}_{5} \mathrm{mg} \mathrm{l}^{-1}$ & 48.3 & Cr ppm & 0.09 \\
\hline $\mathrm{NH}_{4}^{+}-\mathrm{N} \mathrm{mg} \mathrm{l}^{-1}$ & 23.6 & & \\
\hline
\end{tabular}

are presented in Table (1).

\subsection{Wastewater quality criteria}

The wastewater used in the current study was characterized by normal values of $\mathrm{EC}, \mathrm{pH}, \mathrm{NH} 4-$ $\mathrm{N}$, and phosphorous (Table 1). The wastewater had also a slightly higher content of organic matter as indicated by $\mathrm{BOD}_{5}$ values. The presence of these chemical components (nutrients and organic matter) in treated wastewater is very interesting from an agronomic point of view, since they represent important nutrients for improving soil fertility and plant growth. Concentration of heavy metals $(\mathrm{Pb}, \mathrm{Cd}$ and $\mathrm{Ni})$ was in acceptable limits except $\mathrm{Cd}$ which was higher than expected and reached $0.07 \mathrm{ppm}$ (Ayers and Westcot, 1985). The bacteriological investigation has not been carried out in the wastewater samples.

\subsection{Plant analysis}

With regard to plant samples, in August 2018, leaf concentrations of macro-nutrients and heavy metals were determined in the blades sampled. Leaves from the marked trees in each treatment were bulked to form one sample per treatment (36 samples in all). Plant samples were washed with distilled water then, oven dried at $70^{\circ} \mathrm{C}$ until constant weight. Samples were then chopped with a stainless steel pair of scissors and finely ground in a stainless steel miller. The powder produced from the mill was used for the analysis of the heavy metal contents of the vegetation samples. Heavy metal contents in dry leaves were measured by the methods recommended by Chapman and Pratt (1961) as 
1gram of the ground leaves material was ashed then, $\mathrm{Pb}, \mathrm{Cd}$, and $\mathrm{Ni}$, were measured by using Atomic Absorption Spectroscopy. Potassium (K) was measured by flame photometer. Phosphorous was determined by vanadateammonium molybdate method (Chapman and Pratt, 1961). Nitrogen (N) was measured by micro-kjeldahl method (Bremner, 1996). The obtained data were analyzed by two ways ANOVA split plot design. Then, means were compared by Duncan's multiple range tests at 0.05 probability using CoStat v. 6.4. software (CoStat 2005) as described by Snedecor and Cochran (1980)

\subsection{Growth parameters \\ 3. RESULTS \\ 3.1.1. Gmelina arborea seedlings}

The irrigation amounts and systems had a relevant influence on growth and biomass of Gmelina arborea seedlings (Table 2). Height growth increased generally with the amount of irrigation water, therefore $\mathrm{A} 1$ was the highest in the three seasons. Although, the amount of irrigation water did not affect $\mathrm{DBH}$ and $\mathrm{BA}$ significantly in the first season, significantly higher values were obtained by using A1 than $\mathrm{A} 2$ and $\mathrm{A} 3$ in the second and third seasons. Branch numbers were significantly the highest

Table (2): Effect of different amounts of wastewater and irrigation systems on growth parameters, above ground dry biomass and water use efficiency of Gmelina arborea seedlings during three seasons (2016, 2017 and 2018).

\begin{tabular}{|c|c|c|c|c|c|c|}
\hline $\begin{array}{l}\text { Irrigation } \\
\text { levels }\end{array}$ & $\begin{array}{c}\text { Height } \\
(\mathrm{cm})\end{array}$ & $\begin{array}{l}\text { DBH } \\
(\mathbf{c m})\end{array}$ & Branch No. & $\underset{\left(\mathbf{m}^{\mathbf{2}} \mathbf{h a}^{-\mathbf{1}}\right)}{\mathbf{B A}}$ & $\begin{array}{c}\text { Above } \\
\text { ground } \\
\text { Biomass } \\
\text { (kg D.W.) }\end{array}$ & $\begin{array}{c}\text { WUE } \\
\left(\begin{array}{c}\text { kg D.W.W.m } \\
\left.\text { ha' }^{-1}\right)\end{array}\right.\end{array}$ \\
\hline \multicolumn{7}{|c|}{$1^{\text {st }}$ season } \\
\hline A1 & $277.42^{\mathrm{a}}$ & $3.07^{\mathrm{a}}$ & $1.25^{\mathrm{ab}}$ & $0.84^{\mathrm{a}}$ & - & - \\
\hline A2 & $272.92^{b}$ & $3.07^{\mathrm{a}}$ & $1.50^{\mathrm{a}}$ & $0.90^{\mathrm{a}}$ & - & - \\
\hline A3 & $254.25^{\mathrm{c}}$ & $3.16^{\mathrm{a}}$ & $1.08^{\mathrm{b}}$ & $0.91^{\mathrm{a}}$ & - & - \\
\hline \multicolumn{7}{|c|}{$2^{\text {nd }}$ season } \\
\hline A1 & $349.33^{\mathrm{a}}$ & $4.31^{\mathrm{a}}$ & $1.70^{\mathrm{a}}$ & $1.72^{\mathrm{a}}$ & - & - \\
\hline A2 & $318.33^{b}$ & $3.98^{\mathrm{b}}$ & $1.78^{\mathrm{a}}$ & $1.5^{\mathrm{b}}$ & - & - \\
\hline A3 & $281.50^{c}$ & $3.24^{\mathrm{c}}$ & $1.27^{\mathrm{b}}$ & $0.93^{\mathrm{c}}$ & - & - \\
\hline \multicolumn{7}{|c|}{$3^{r d}$ season } \\
\hline A1 & $413.25^{\mathrm{a}}$ & $5.74^{\mathrm{a}}$ & $1.82^{\mathrm{a}}$ & $3.05^{\mathrm{a}}$ & $10.25^{\mathrm{a}}$ & $0.81^{\mathrm{b}}$ \\
\hline A2 & $407.00^{\mathrm{a}}$ & $4.98^{\mathrm{b}}$ & $1.83^{\mathrm{a}}$ & $2.38^{\mathrm{b}}$ & $7.92^{\mathrm{b}}$ & $0.84^{\mathrm{b}}$ \\
\hline A3 & $310.33^{b}$ & $3.83^{\mathrm{c}}$ & $1.62^{\mathrm{b}}$ & $1.36^{\mathrm{c}}$ & $6.08^{\mathrm{c}}$ & $0.97^{\mathrm{a}}$ \\
\hline \multicolumn{7}{|l|}{$\begin{array}{c}\text { Irrigation } \\
\text { system }\end{array}$} \\
\hline \multicolumn{7}{|c|}{$1^{\text {st }}$ season } \\
\hline Bub. & $358.89^{\mathrm{a}}$ & $3.88^{\mathrm{a}}$ & $1.22^{\mathrm{a}}$ & $1.32^{\mathrm{a}}$ & - & - \\
\hline Drip. & $295.45^{\mathrm{b}}$ & $3.62^{\mathrm{b}}$ & $1.22^{\mathrm{a}}$ & $1.15^{\mathrm{b}}$ & - & - \\
\hline G. R. & $247.11^{\mathrm{c}}$ & $2.49^{\mathrm{c}}$ & $1.22^{\mathrm{a}}$ & $0.54^{\mathrm{c}}$ & - & - \\
\hline SSD & $171.33^{\mathrm{d}}$ & $2.40^{\mathrm{d}}$ & $1.44^{\mathrm{a}}$ & $0.52^{\mathrm{c}}$ & - & - \\
\hline \multicolumn{7}{|c|}{$2^{n d}$ season } \\
\hline Bub. & $421.89^{\mathrm{a}}$ & $5.18^{\mathrm{a}}$ & $1.66^{\mathrm{a}}$ & $2.41^{\mathrm{a}}$ & - & - \\
\hline Drip. & $371.56^{\mathrm{b}}$ & $3.89^{\mathrm{b}}$ & $1.47^{\mathrm{a}}$ & $1.36^{\mathrm{b}}$ & - & - \\
\hline G. R. & $283.67^{\mathrm{c}}$ & $3.31^{\mathrm{c}}$ & $1.49^{\mathrm{a}}$ & $0.97^{\mathrm{c}}$ & - & - \\
\hline SSD & $188.44^{\mathrm{d}}$ & $2.99^{\mathrm{d}}$ & $1.69^{\mathrm{a}}$ & $0.79^{d}$ & - & - \\
\hline \multicolumn{7}{|c|}{$3^{r d}$ season } \\
\hline Bub. & $511.33^{\mathrm{a}}$ & $6.79^{\mathrm{a}}$ & $1.81^{\mathrm{a}}$ & $4.12^{\mathrm{a}}$ & $12.11^{\mathrm{a}}$ & $1.31^{\mathrm{a}}$ \\
\hline Drip. & $439.89^{b}$ & $5.17^{\mathrm{b}}$ & $1.73^{\mathrm{a}}$ & $2.42^{\mathrm{b}}$ & $9.22^{\mathrm{b}}$ & $0.99^{b}$ \\
\hline G. R. & $335.22^{\mathrm{c}}$ & $4.05^{\mathrm{c}}$ & $1.70^{\mathrm{a}}$ & $1.49^{c}$ & $7.00^{c}$ & $0.75^{\mathrm{c}}$ \\
\hline SSD & $221.00^{\mathrm{d}}$ & $3.40^{\mathrm{d}}$ & $1.78^{\mathrm{a}}$ & $1.03^{\mathrm{d}}$ & $4.00^{\mathrm{d}}$ & $0.42^{\mathrm{d}}$ \\
\hline
\end{tabular}

Means followed by a similar letter within a column are not significantly different at the probability level 0.05 using Duncan's Multiple Range Test. A $1=130 \%, \mathrm{~A} 2=100 \%$, A3=70\%evapotranspiration. Irrigation system Bubblers (Bub.), on line dripper (Drip.), built-in dripper (G.R.) and sub-surface drip irrigation (SSD). 
at $\mathrm{A} 1$ or $\mathrm{A} 2$ compared to $\mathrm{A} 3$. The highest values of height, DBH and BA however, were detected with using Bubblers followed by Drip. then G.R. and SSD. Branch number was not affected by irrigation systems being used in the three seasons. The interaction effect of the amount of wastewater and irrigation system on growth parameters was significant (Fig.1). The amount of irrigation A2 (7.7 1 tree $\left.\mathrm{day}^{-1}\right)$ with Bubblers produced the tallest growth through the three seasons, the wider growth (DBH) and the maximum value of $\mathrm{BA}$ in the first season. The treatment A1 (10.3 1 tree $^{-1}$ day $\left.^{-1}\right)$ with Bubblers, produced the wider $\mathrm{DBH}$ and the maximum value of $\mathrm{BA}$ in the second and third seasons.

As observed from this experiment, the maximum branch number was obtained by application of A1 with SSD system in the second and third seasons. Conversely, the least irrigation amount A3 with SSD system produced the lowest values of growth height, $\mathrm{DBH}$, branch number and BA.

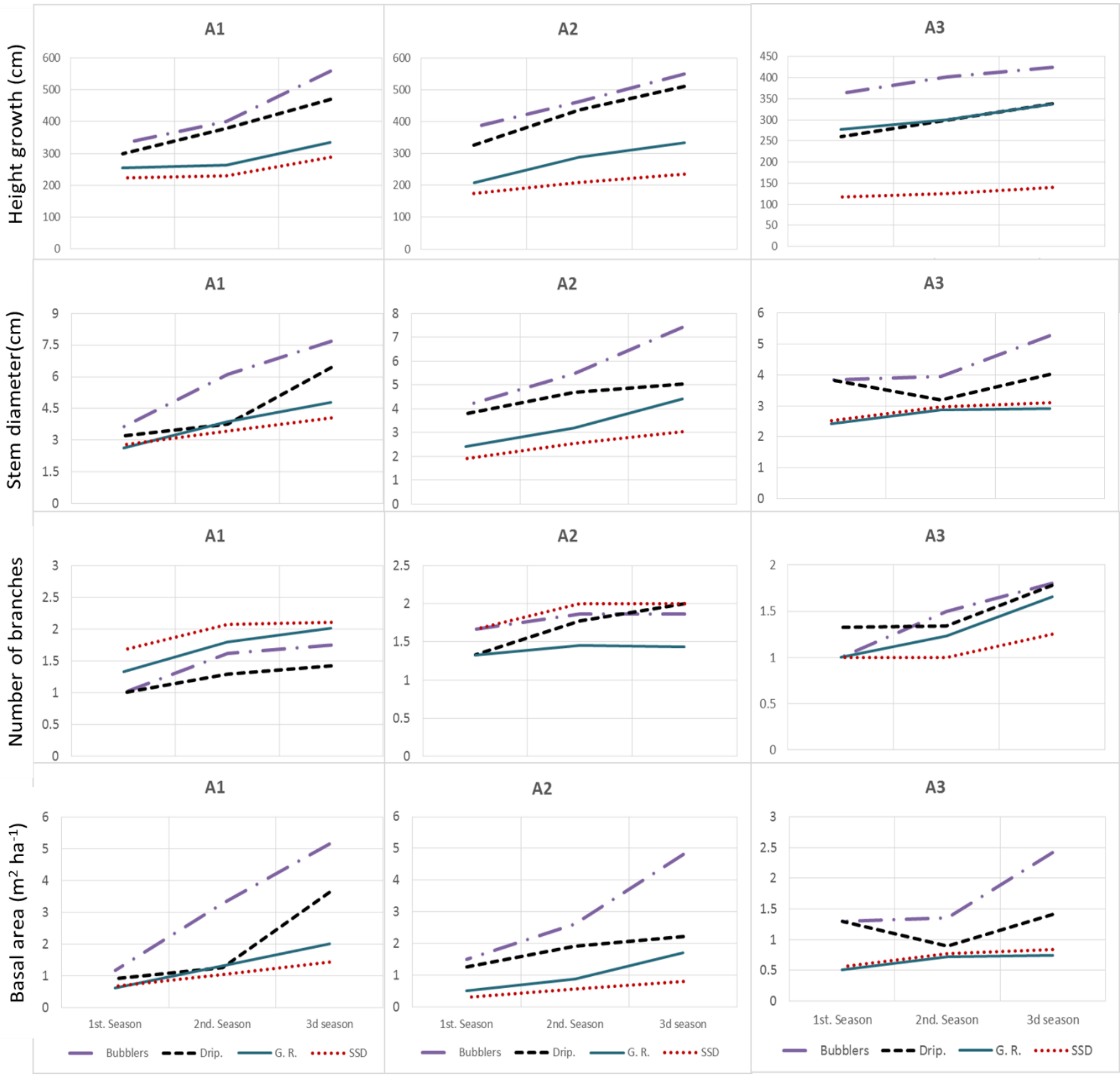

Fig. (1): The interaction of different amounts of wastewater and irrigation systems on growth parameters and aboveground dry biomass of Gmelina arborea seedlings during three seasons. A1=130\%, $\mathrm{A} 2=100 \%, \mathrm{~A} 3=\mathbf{7 0} \%$ evapotranspiration. 


\subsubsection{Khaya senegalensis seedlings}

The irrigation amounts and systems had a substantial impact on the growth and biomass of Khaya senegalensis seedlings (Table 3 ). The data revealed that the highest irrigation amount (A1) significantly increased plant height comparing with $\mathrm{A} 2$ and $\mathrm{A} 3$ treatments across the three seasons. The reduction in plant height due to A2 and A3 treatments recorded 17.0 and $24.2 \%$, respectively in the second season and 14.9 and $20.2 \%$, respectively in the third season, lower than those of A1 treatment. Both of DBH and $\mathrm{BA}$ showed a similar trend, which were increased appreciably by A1 treatment throughout the three successive seasons followed by $\mathrm{A} 2$ and $\mathrm{A} 3$ treatments. The response of branch number to irrigation treatments varied from season to another. It increased with A1 treatment at the third season, while it was the highest at $\mathrm{A} 2$ and $\mathrm{A} 3$ treatments in both the first and second seasons.

The additive effects of Bubblers system are evident from Table (3), where it produced the tallest seedlings $(191.65,246.00$ and $296.33 \mathrm{~cm})$ with wider DBH $(2.11,2.76$, and $3.67 \mathrm{~cm})$ and the greatest BA $\left(0.41,0.68\right.$, and $\left.1.20 \mathrm{~m}^{2} \mathrm{ha}^{-1}\right)$ in the three consecutive seasons, respectively. The effect of irrigation system on branch number was visible in the second and third seasons, whereas branch numbers were the highest with using Bubblers system compared with any other irrigation system. Drip. and bubblers systems approximately gave similar trend at irrigation amount $\mathrm{A} 1$, which produced the maximum $\mathrm{DBH}$ and BA values in the third season. Although the results of branch number were not obvious in the first and second seasons, but the highest values were obtained by using Bubblers under the

Table (3): Effect of different amounts of wastewater and irrigation systems on growth parameters, above ground dry biomass and water use efficiency of Khaya senegalensis seedlings during three seasons (2016, 2017 and 2018).

\begin{tabular}{|c|c|c|c|c|c|c|}
\hline $\begin{array}{l}\text { Irrigation } \\
\text { levels }\end{array}$ & $\begin{array}{c}\text { Height } \\
\text { (cm) }\end{array}$ & $\begin{array}{l}\text { DBH } \\
(\mathrm{cm})\end{array}$ & Branch No. & $\begin{array}{c}\text { BA } \\
\left(\mathbf{m}^{2} \mathbf{h a}^{-1}\right)\end{array}$ & $\begin{array}{c}\text { Above ground } \\
\text { Biomass } \\
\text { (kg D.W.) } \\
\end{array}$ & $\begin{array}{c}\text { WUE } \\
\left(\begin{array}{l}\text { kg D.W. } \\
\left.h^{-1}\right)\end{array}\right. \\
\end{array}$ \\
\hline \multicolumn{7}{|c|}{$\mathbf{1}^{\text {st }}$ season } \\
\hline A1 & $149.44^{\mathrm{a}}$ & $1.89^{\mathrm{a}}$ & $\overline{1.08^{\mathrm{b}}}$ & $0.33^{\mathrm{a}}$ & - & - \\
\hline A2 & $143.93^{b}$ & $1.78^{\mathrm{b}}$ & $1.50^{\mathrm{a}}$ & $0.28^{b}$ & - & - \\
\hline A3 & $140.52^{\mathrm{c}}$ & $1.58^{\mathrm{c}}$ & $1.42^{\mathrm{a}}$ & $0.23^{\mathrm{c}}$ & - & - \\
\hline \multicolumn{7}{|c|}{$2^{\text {nd }}$ season } \\
\hline A1 & $229.92^{\mathrm{a}}$ & $2.84^{\mathrm{a}}$ & $1.38^{\mathrm{b}}$ & $0.72^{\mathrm{a}}$ & - & - \\
\hline $\mathrm{A} 2$ & $195.67^{b}$ & $2.57^{b}$ & $1.85^{\mathrm{a}}$ & $0.58^{b}$ & - & - \\
\hline A3 & $183.5^{\mathrm{c}}$ & $2.33^{\mathrm{c}}$ & $1.71^{\mathrm{a}}$ & $0.48^{\mathrm{c}}$ & - & - \\
\hline \multicolumn{7}{|c|}{$3^{r d}$ season } \\
\hline A1 & $275.08^{\mathrm{a}}$ & $3.73^{\mathrm{a}}$ & $3.59^{\mathrm{a}}$ & $1.25^{\mathrm{a}}$ & $13.00^{\mathrm{a}}$ & $1.03^{b}$ \\
\hline $\mathrm{A} 2$ & $228.25^{b}$ & $3.22^{\mathrm{b}}$ & $2.81^{b}$ & $0.91^{\mathrm{b}}$ & $10.17^{b}$ & $1.07^{\mathrm{b}}$ \\
\hline $\mathrm{A} 3$ & $208.42^{b}$ & $2.92^{\mathrm{c}}$ & $2.63^{\mathrm{c}}$ & $0.75^{\mathrm{c}}$ & $8.38^{\mathrm{c}}$ & $1.33^{\mathrm{a}}$ \\
\hline \multicolumn{7}{|l|}{$\begin{array}{l}\text { Irrigation } \\
\text { system }\end{array}$} \\
\hline \multicolumn{7}{|c|}{$1^{s t}$ season } \\
\hline Bub. & $191.65^{\mathrm{a}}$ & $2.11^{\mathrm{a}}$ & $1.56^{\mathrm{a}}$ & $0.41^{\mathrm{a}}$ & - & - \\
\hline Drip. & $142.39^{b}$ & $1.47^{\mathrm{c}}$ & $1.44^{\mathrm{a}}$ & $0.19^{c}$ & - & - \\
\hline G. R. & $128.15^{\mathrm{c}}$ & $1.68^{b}$ & $1.00^{\mathrm{a}}$ & $0.25^{b}$ & - & - \\
\hline SSD & $116.33^{\mathrm{d}}$ & $1.73^{\mathrm{b}}$ & $1.33^{\mathrm{a}}$ & $0.27^{\mathrm{b}}$ & - & - \\
\hline \multicolumn{7}{|c|}{$2^{\text {nd }}$ season } \\
\hline Bub. & $246.00^{\mathrm{a}}$ & $2.76^{\mathrm{a}}$ & $1.98^{\mathrm{a}}$ & $0.68^{\mathrm{a}}$ & - & - \\
\hline Drip. & $194.00^{b}$ & $2.57^{\mathrm{bc}}$ & $1.75^{\mathrm{b}}$ & $0.61^{\mathrm{ab}}$ & - & - \\
\hline G. R. & $192.33^{b}$ & $2.59^{b}$ & $1.44^{\mathrm{c}}$ & $0.59^{\mathrm{b}}$ & - & - \\
\hline SSD & $179.78^{\mathrm{c}}$ & $2.41^{\mathrm{c}}$ & $1.41^{\mathrm{c}}$ & $0.51^{\mathrm{c}}$ & - & - \\
\hline \multicolumn{7}{|c|}{$\mathbf{3}^{r d}$ season } \\
\hline Bub. & $296.33^{\mathrm{a}}$ & $3.67^{\mathrm{a}}$ & $3.93^{\mathrm{a}}$ & $1.20^{\mathrm{a}}$ & $15.33^{\mathrm{a}}$ & $1.69^{\mathrm{a}}$ \\
\hline Drip. & $227.89^{b}$ & $3.58^{\mathrm{a}}$ & $2.98^{b}$ & $1.15^{\mathrm{a}}$ & $12.33^{b}$ & $1.35^{\mathrm{b}}$ \\
\hline G. R. & $215.11^{b}$ & $3.22^{\mathrm{b}}$ & $2.62^{\mathrm{C}}$ & $0.91^{\mathrm{b}}$ & $9.56^{\mathrm{c}}$ & $1.03^{\mathrm{c}}$ \\
\hline SSD & $209.67^{b}$ & $2.68^{\mathrm{c}}$ & $2.50^{\mathrm{c}}$ & $0.63^{\mathrm{c}}$ & $4.83^{\mathrm{d}}$ & $0.50^{\mathrm{d}}$ \\
\hline
\end{tabular}

Means followed by a similar letter within a column are not significantly different at the probability level 0.05 using Duncan's Multiple Range Test.A1 $=130 \%$, A2 $=100 \%$, A3=70\%evapotranspiration. Irrigation system Bubblers (Bub.), on line dripper 
irrigation amount A1.

The highest irrigation amount (A1) with bubblers produced the tallest and wider growth of $K$. senegalensis throughout the three seasons (Fig. 2). The Drip. irrigation system was significantly similar with Bubblers at the highest irrigation rate which produced the maximum DBH and BA values in the third season.
Although the results of branch number were not clear in the first and second seasons, but the maximum number of branches was obtained by using Bubblers under the highest irrigation rate. In contract, the Drip. and SSD systems under the lowest amount of water (A3) produced the minimum plant height, $\mathrm{DBH}$, branch number and BA through the three seasons.

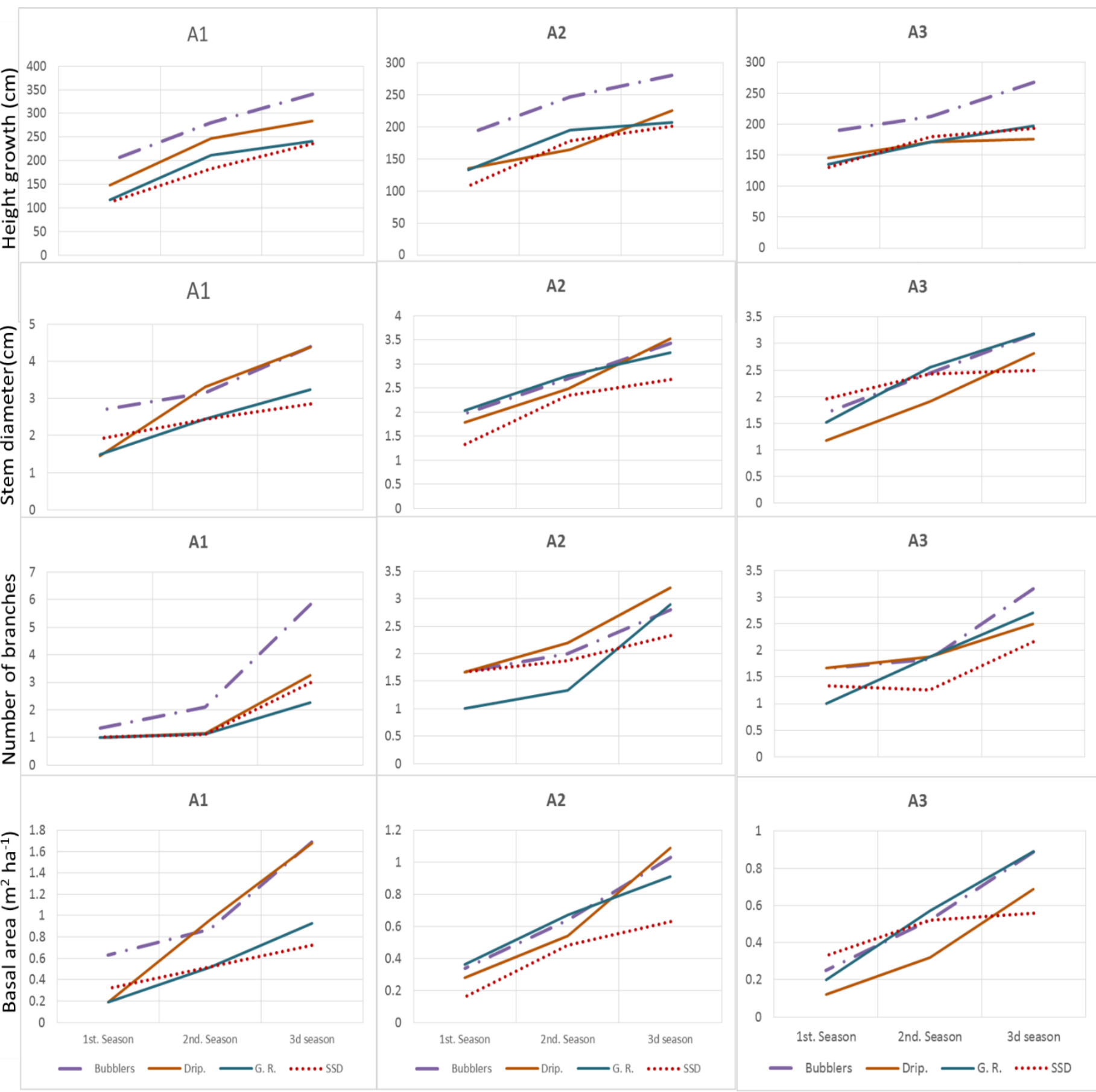

Fig. (2): The interaction of different amounts of wastewater and irrigation systems on the growth parameters and aboveground dry biomass of Khaya senegalensis seedlings during three seasons. A1=130\%, A2=100\%, A3 $=70 \%$ evapotranspiration. 


\subsubsection{Tectona grandis seedlings}

Data in Table (4) showed that the highest irrigation amount (A1) significantly increased plant height of Tectona grandis seedlings compared with $\mathrm{A} 2$ and $\mathrm{A} 3$ treatments during the three seasons. The plant height increased with application of A1 which recorded $260.58 \mathrm{~cm}$, while it was reduced by 12.7 and $29.4 \%$ at A2 and A3 in the second season, respectively. Similar trend was observed in the third season, where A1 treatment recorded the tallest plants comparing with other amounts (A2 and A3) which recorded a reduction of 12.7 and $23.2 \%$, respectively. Both of $\mathrm{DBH}$ and $\mathrm{BA}$ were increased substantially, byA1 during the three successive seasons followed by A2 and A3 treatments. The response of branch number to irrigation treatments were insignificant in the first and second seasons, while it was increased significantly by using A1 at the third season.

Table (4) concluded that using Bubblers system, produced the tallest $T$. grandis seedlings (213.0, 294.89 and $359.33 \mathrm{~cm})$ in the three successive seasons, respectively, the wider DBH $(3.73$ and $4.96 \mathrm{~cm})$ and the greatest BA $(1.25$ and $2.28 \mathrm{~m}^{2} \mathrm{ha}^{-1}$ ) in the second and third seasons, respectively. However, the effect of irrigation system on branch number was undetectable in the first and second seasons, beside no reasonable trend was observed in the third season. The irrigation amount A1 with Bubblers produced the tallest $T$. grandis seedlings in second and third seasons (Fig. 3). Additionally, the Bubblers system gave approximately the maximum $\mathrm{DBH}$ at irrigation amount $\mathrm{A} 1$ in the second and third seasons. Althoug the results

Table (4): Effect of different amounts of wastewater and irrigation systems on the growth parameters, above ground dry biomass and water use efficiency of Tectona grandis seedlings during three seasons (2016, 2017 and 2018).

\begin{tabular}{|c|c|c|c|c|c|c|}
\hline $\begin{array}{l}\text { Irrigation } \\
\text { levels }\end{array}$ & $\begin{array}{c}\text { Height } \\
(\mathbf{c m})\end{array}$ & $\begin{array}{c}\text { DBH } \\
(\mathbf{c m})\end{array}$ & Branch No. & $\underset{\left(\mathbf{m}^{2} \mathbf{h a}^{-1}\right)}{\mathbf{B A}}$ & $\begin{array}{l}\text { Above ground } \\
\text { Biomass } \\
\text { (kg D.W.) }\end{array}$ & $\begin{array}{c}\text { WUE } \\
\left(\begin{array}{c}\text { kg D.W. } \mathrm{m}^{3} \\
\left.\text { ha }^{-1}\right)\end{array}\right.\end{array}$ \\
\hline \multicolumn{7}{|c|}{$1^{\text {st }}$ season } \\
\hline A1 & $187.59^{\mathrm{a}}$ & $1.98^{\mathrm{a}}$ & $1.08^{\mathrm{a}}$ & $0.35^{\mathrm{a}}$ & - & - \\
\hline A2 & $179.67^{\mathrm{b}}$ & $1.93^{\mathrm{a}}$ & $1.0^{\mathrm{a}}$ & $0.33^{\text {ab }}$ & - & - \\
\hline A3 & $160.5^{\mathrm{c}}$ & $1.79^{\mathrm{b}}$ & $1.0^{\mathrm{a}}$ & $0.30^{\mathrm{b}}$ & - & - \\
\hline \multicolumn{7}{|c|}{$2^{\text {nd }}$ season } \\
\hline A1 & $260.58^{\mathrm{a}}$ & $2.93^{\mathrm{a}}$ & $1.20^{\mathrm{a}}$ & $0.79^{\mathrm{a}}$ & - & - \\
\hline $\mathrm{A} 2$ & $227.42^{\mathrm{b}}$ & $2.50^{\mathrm{b}}$ & $1.06^{\mathrm{a}}$ & $0.57^{\mathrm{b}}$ & - & - \\
\hline A3 & $184.0^{\mathrm{c}}$ & $2.58^{\mathrm{b}}$ & $1.08^{\mathrm{a}}$ & $0.69^{\mathrm{a}}$ & - & - \\
\hline \multicolumn{7}{|c|}{$\mathbf{3}^{r d}$ season } \\
\hline A1 & $312.42^{\mathrm{a}}$ & $3.66^{\mathrm{a}}$ & $2.12^{\mathrm{a}}$ & $1.30^{\mathrm{a}}$ & $29.92^{\mathrm{a}}$ & $2.36^{\mathrm{b}}$ \\
\hline A2 & $272.83^{\mathrm{b}}$ & $2.91^{\mathrm{c}}$ & $1.59^{\mathrm{b}}$ & $0.78^{\mathrm{c}}$ & $22.33^{b}$ & $2.35^{\mathrm{b}}$ \\
\hline A3 & $239.92^{\mathrm{c}}$ & $3.14^{\mathrm{b}}$ & $1.98^{\mathrm{a}}$ & $1.11^{\mathrm{b}}$ & $16.33^{\mathrm{c}}$ & $2.60^{\mathrm{a}}$ \\
\hline \multicolumn{7}{|l|}{$\begin{array}{l}\text { Irrigation } \\
\text { system }\end{array}$} \\
\hline \multicolumn{7}{|c|}{$1^{\text {st }}$ season } \\
\hline Bub. & $213.0^{\mathrm{a}}$ & $2.02^{\mathrm{a}}$ & $\overline{1.00^{\mathrm{a}}}$ & $0.36^{\mathrm{a}}$ & - & - \\
\hline Drip. & $205.33^{\mathrm{b}}$ & $2.08^{\mathrm{a}}$ & $1.00^{\mathrm{a}}$ & $0.39^{\mathrm{a}}$ & - & - \\
\hline G. R. & $160.0^{c}$ & $2.06^{\mathrm{a}}$ & $1.00^{\mathrm{a}}$ & $0.37^{\mathrm{a}}$ & - & - \\
\hline SSD & $125.33^{\mathrm{d}}$ & $1.46^{\mathrm{b}}$ & $1.11^{\mathrm{a}}$ & $0.20^{\mathrm{b}}$ & - & - \\
\hline \multicolumn{7}{|c|}{$2^{n d}$ season } \\
\hline Bub. & $294.89^{\mathrm{a}}$ & $3.73^{\mathrm{a}}$ & $1.11^{\mathrm{ab}}$ & $1.25^{\mathrm{a}}$ & - & - \\
\hline Drip. & $227.67^{b}$ & $2.69^{b}$ & $1.11^{\mathrm{ab}}$ & $0.69^{b}$ & - & - \\
\hline G. R. & $203.44^{b}$ & $2.33^{\mathrm{c}}$ & $1.09^{\mathrm{b}}$ & $0.47^{\mathrm{c}}$ & - & - \\
\hline SSD & $170.00^{c}$ & $1.92^{\mathrm{d}}$ & $1.14^{\mathrm{a}}$ & $0.32^{\mathrm{d}}$ & - & - \\
\hline \multicolumn{7}{|c|}{$\mathbf{3}^{r d}$ season } \\
\hline Bub. & $359.33^{\mathrm{a}}$ & $4.96^{\mathrm{a}}$ & $1.85^{\mathrm{a}}$ & $2.28^{\mathrm{a}}$ & $39.78^{\mathrm{a}}$ & $4.20^{\mathrm{a}}$ \\
\hline Drip. & $290.89^{b}$ & $3.35^{\mathrm{b}}$ & $2.08^{\mathrm{a}}$ & $1.02^{\mathrm{b}}$ & $23.33^{b}$ & $2.48^{b}$ \\
\hline G. R. & $248.78^{\mathrm{c}}$ & $2.54^{\mathrm{c}}$ & $1.83^{\mathrm{a}}$ & $0.57^{\mathrm{c}}$ & $16.11^{\mathrm{c}}$ & $1.75^{\mathrm{c}}$ \\
\hline SSD & $201.22^{\mathrm{d}}$ & $2.08^{\mathrm{d}}$ & $1.83^{\mathrm{a}}$ & $0.38^{\mathrm{d}}$ & $12.22^{\mathrm{d}}$ & $1.31^{\mathrm{d}}$ \\
\hline
\end{tabular}

Means followed by a similar letter within a column are not significantly different at the probability level 0.05 using Duncan's Multiple Range Test.A1 $=130 \%$, A2 $=100 \%$, A3 $=70 \%$ evapotranspiration. Irrigation system Bubblers (Bub.), on line dripper (Drip.), built-in dripper (G.R.) and sub-surface drip irrigation (SSD). 


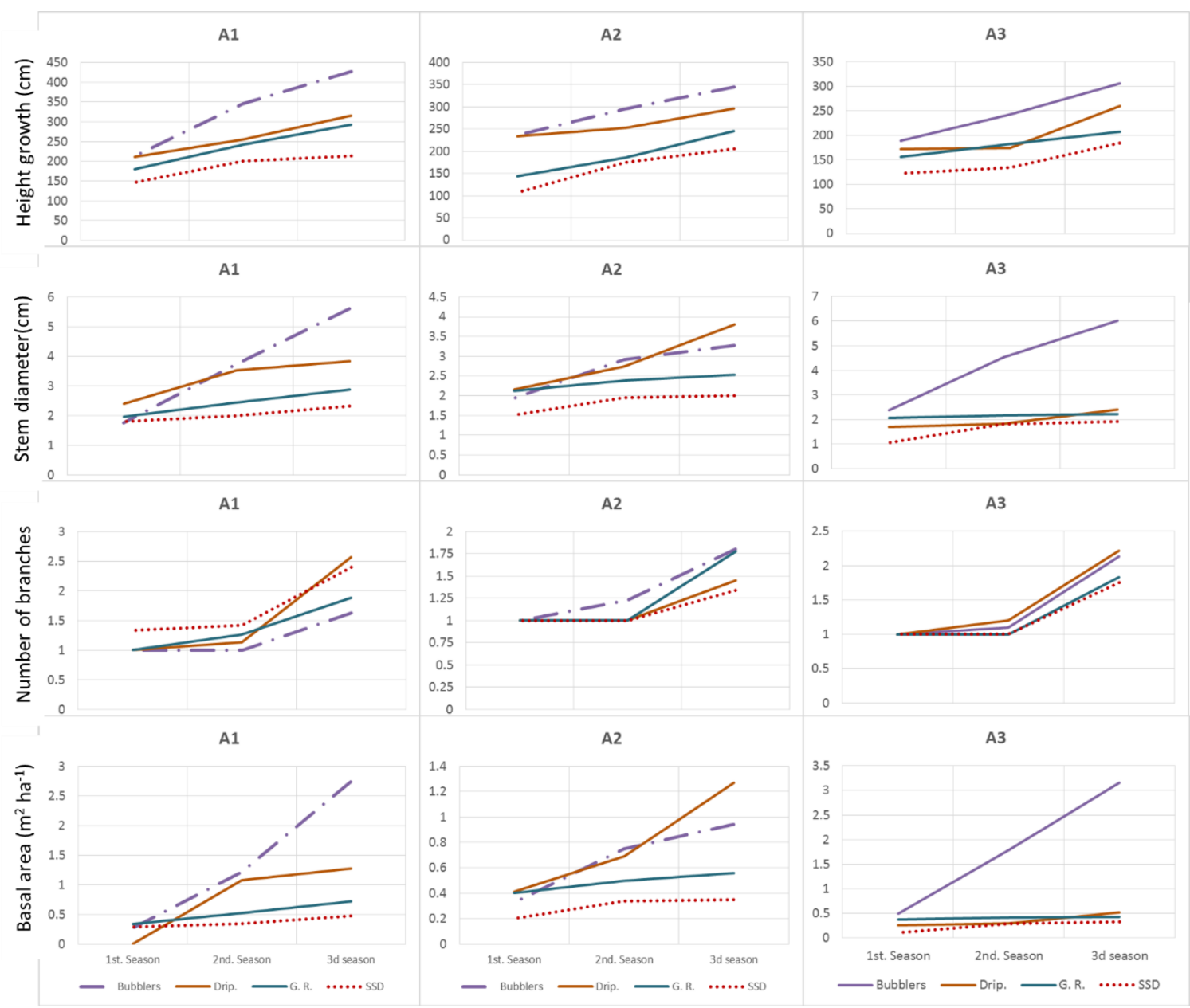

Fig. (3): The interaction of different amounts of wastewater and irrigation systems on growth parameters and aboveground dry biomass of Tectona grandis seedlings during three seasons. $\mathrm{A} 1=130 \%, \mathrm{~A} 2=100 \%, \mathrm{~A} 3=\mathbf{7 0} \%$ evapotranspiration.

of branch number were not significant in the first and second seasons, the highest values were obtained by using Drip. under irrigation amount A1 in the third season. On the other hand, using the SSD at A2 irrigation amount produced the minimum branch number in the third season. Using Bubblers system with amount A3 gave the highest $\mathrm{BA}$ in the three seasons, whereas the lowest BA was recorded under A3 with SSD. Moreover, using amount of water A3 under SSD system gave the shortest seedlings, the greatest $\mathrm{BA}$ and DBH in the three seasons.

\subsection{Above ground biomass and water use efficiency}

\subsubsection{Above ground biomass}

The results showed that the effect of different irrigation amounts was noticeable on the above ground biomass of G. arborea (Table 2). After three growing seasons, the huge biomass was obtained with A1 treatment which recorded $(10.25 \mathrm{~kg})$ and reduced by 22.7 and $40.7 \%$ compared with A2 and A3 treatments, respectively. The Bub. system was the superior which increased the above ground biomass comparing with other systems. For instance, using Drip., G.R. and SSD systems reduced biomass by $23.9,42.2$, and $67.0 \%$ comparing with Bubblers system, respectively. The treatment A1 (10.3 1 tree $^{-1}$ day $\left.^{-1}\right)$ with Bubblers gave the greatest biomass in the third season. Conversely, the least irrigation amount A3 with SSD system produced the lowest value of biomass. The aboveground biomass of $K$. senegalensis seedlings was statistically significant and gave the highest biomass yield at irrigation amount A1, the corresponding reduction was accounted 21.8 and $35.6 \%$ under $\mathrm{A} 2$ and $\mathrm{A} 3$ treatments, respectively. In addition, 
biomass of $K$. senegalensis was the highest with using Bubblers, and then reduced by using Drip., G.R. and SSD irrigation systems, giving 19.6, 37.6 and $68.5 \%$ reduction, respectively. The irrigation amount A1 with Bub. system produced the highest above ground biomass of $K$. senegalensis. In contract, using the Drip. and SSD at A3 irrigation amount produced the minimum aboveground biomass in the third season (Table 3). Similarly, biomass of $T$. grandis seedlings was statistically significant and detected the highest yield at irrigation amount A1(29.92 kg DW), subsequently reduced by 25.0 and $45.4 \%$ at $\mathrm{A} 2$ and $\mathrm{A} 3$ treatments, respectively. Likewise, biomass was the highest with using Bubblers followed by Drip., then G.R. and SSD irrigation systems, at which the reduction obtained recorded 41.4, 59.5, and $69.3 \%$, respectively.

Also, the irrigation amount A1 with Bubblers had the highest above ground biomass of $T$. grandis. Whereas using amount A3 under SSD system gave the least biomass in the third season (Table 4).

\subsubsection{Water use efficiency (WUE)}

Water use efficiency was significantly affected by the amount of wastewater treatments for G. arborea. The results showed that WUE responded equally to $\mathrm{A} 1$ and $\mathrm{A} 2$ treatments ( 0.81 and $0.84 \mathrm{~kg}$ D.W. $\mathrm{m}^{3} \mathrm{ha}^{-1}$ ) and then increased visibly with using A3 treatment (0.97 $\mathrm{kg}$ D.W. $\mathrm{m}^{3} \mathrm{ha}^{-1}$ ) (Table 2). Similarly, water use efficiency was affected significantly by the type of irrigation systems, in which the Bubblers system gave the highest values compared with any other system used in this study, averaged $1.31, \quad 0.99, \quad 0.75$ and $0.42 \mathrm{kgm}^{-3} \mathrm{ha}^{-1}$ under Bubblers, Drip., G.R. and SSD, respectively. Also, WUE values were usually the highest under Bub. system with A3 treatment, while WUE under SSD and G.R. systems were not affected significantly by the amounts of irrigation water. Consistently, water use efficiency was the highest under A3 treatment for $K$. senegalensis and decreased significantly as amount of wastewater increased to A2treatment (Table 3). This contrasting relationship was confirmed by the results of WUE which gave lower values under higher the amounts of wastewater application, although no differences between A1 and A2 treatments were noticed. Similarly, water use efficiency was affected significantly by the type of irrigation systems, where the highest values were observed using Bub. system compared with Drip., G.R. and SSD averaged 1.69, 1.35, 1.03 and 0.50 $\mathrm{kgm}^{-3} \mathrm{ha}^{-1}$, respectively. In addition the interaction effect revealed that WUE always had the highest values under Bub. followed by Drip. system with the lowest amount of water A3 treatment compared with the other interaction effects (Fig. 4). Lastly, water use efficiency was affected significantly by the amount of wastewater treatments for T. grandis seedlings, being the highest under $\mathrm{A} 3$ and reduced considerably under A1 and A2 treatments, while there was no difference between A1 and A2 treatments (Table 4).

In other words the higher water applied, the lower WUE was recorded. Likewise, water use efficiency was affected significantly by the type of irrigation systems, in which the Bub. system surpassed the other irrigation systems used. Water use efficiency under Bubblers system gave the highest value of $4.20 \mathrm{kgm}^{-3} \mathrm{ha}^{-1}$ and reduced to $2.48,1.75$ and $1.31 \mathrm{kgm}^{-3} \mathrm{ha}^{-1}$ by using Drip., G.R., and SSD, respectively (Table 4). Interaction between irrigation amounts and systems showed that WUE of $T$. grandis seedlings had the highest values in most cases under Bubblers system followed by Drip., then G.R. and SSD. This trend was observed at all
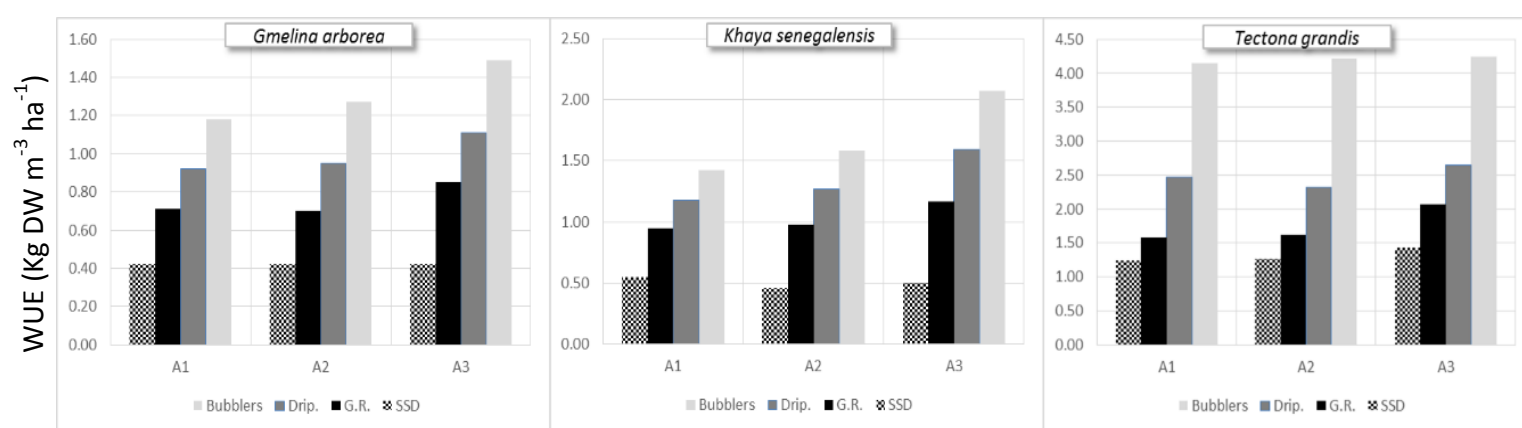

Fig. (4): The interaction of different amounts of wastewater and irrigation systems on water use efficiency of Gmelina arborea, Khaya senegalensis and Tectona grandis seedlings during three seasons. A1=130\%, $\mathbf{A 2}=100 \%, \quad \mathbf{A} 3=70 \%$ evapotranspiration. 
irrigation treatments applied.

\subsection{Nutrients and heavy metal contents}

The highest contents of $\mathrm{N}, \mathrm{P}, \mathrm{K}, \mathrm{Cd}$, the $\mathrm{Pb}$ and $\mathrm{Ni}$ were observed under $\mathrm{A} 1$ treatments in leaves of the three species used in the current study Fig. (5). Conversely, the lowest amount of waste water (A3) treatment resulted in the lowest contents of $\mathrm{N}, \mathrm{P}, \mathrm{K}, \mathrm{Cd}, \mathrm{Pb}$ and $\mathrm{Ni}$ in the leaves.
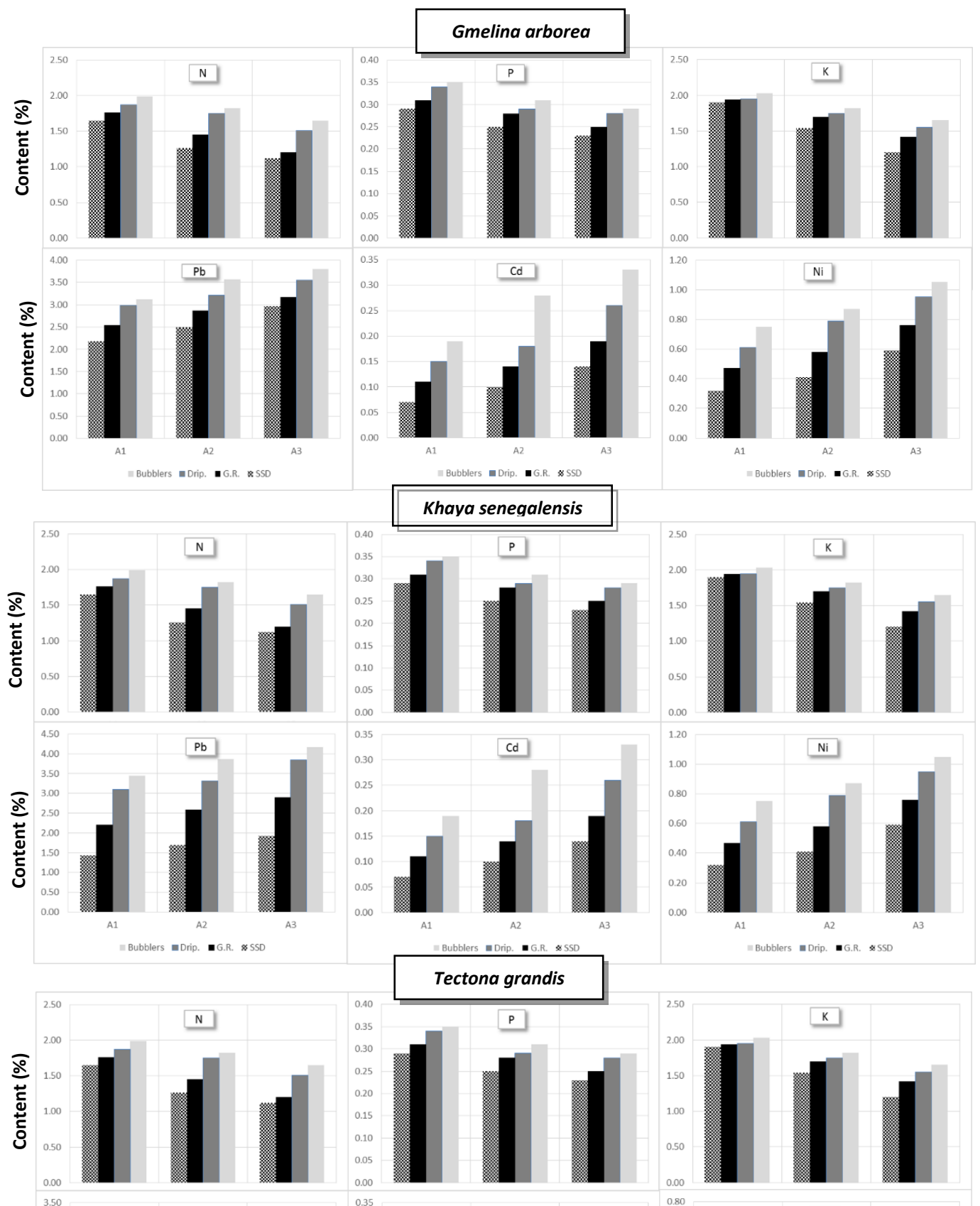

Tectona grandis

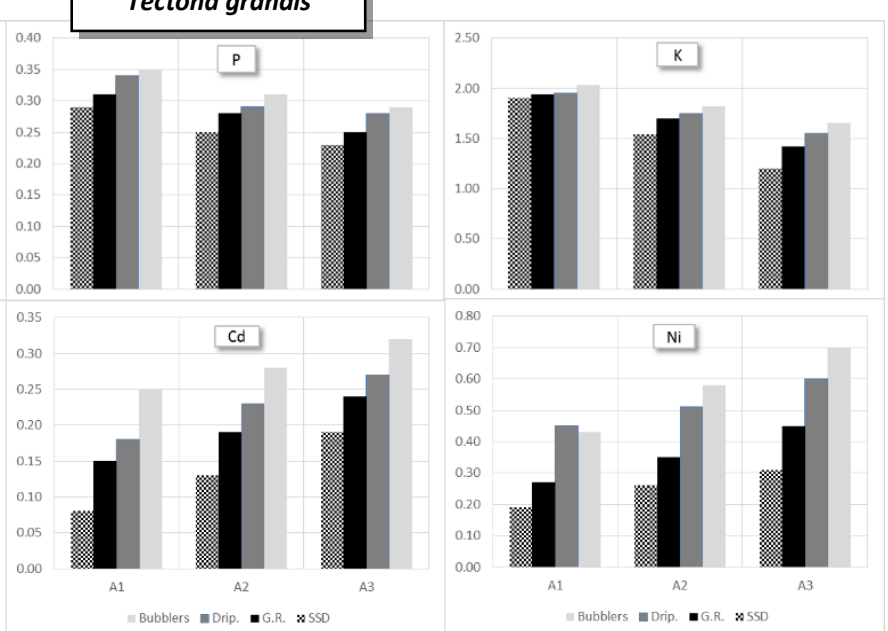

Fig. (5): The effect of different amounts of wastewater and irrigation systems on macro-elements and some heavy metals of Gmelina arborea, Khaya senegalensis and Tectona grandis seedlings at the end of the study. $\mathrm{A} 1=130 \%, \mathrm{~A} 2=100 \%, \mathrm{~A} 3=70 \%$ evapotranspiration 
On the other hand, the content of $\mathrm{N}$ was the highest under Bub. system, while $\mathrm{P}$ content was the highest using Drip. and Bub. Comparing with G.R. and SSD systems in G. arborea and T. grandis seedlings. Potassium content showed the highest values with G.R. system in G. arborea and $T$. grandis seedlings, while using Drip gave the highest content in $K$. senegalensis. Once more, the heavy metal $(\mathrm{Cd}, \mathrm{Pb}$, and $\mathrm{Ni})$ contents in the leaves of the three species were the highest under Bubblers followed by Drip then G.R. and SSD systems.

\section{DISCUSSIONS}

The results of this study revealed that the behavior of the three species (Gmelina arborea, Khaya senegalensis and Tectona grandis) to different amounts of wastewater and irrigation systems were similar, except for few instances. The highest amount of irrigation water (A1; 10.3 1 tree $^{-1}$ day $^{-1}$ ) gave the tallest seedlings, the wider $\mathrm{DBH}$, the greatest $\mathrm{BA}$ and the highest above ground biomass. Conversely, the highest amount of irrigation water (A1) gave the lowest water use efficiency (WUE). Under scarce water in semi-arid areas, irrigation water management aims to provide sufficient water to replenish depleted soil water in time to avoid physiological water stress in growing plants. Moreover, excess water in the soil is detrimental to plant growth, due to oxygen deprivation in the plant's roots zone. However, the soil type has to be taken into account as well. The present study showed that growth parameters and biomass were positively increased with water increasing up to $130 \%$ of evapotranspiration in sandy soils. This response was due to that sandy soil having a small water holding capacity and with irrigation suitable conditions for optimal tree growth was maintained. Therefore, the increase in tree growth may be related to sufficient availability of water in the soil (Larchevệque $e t$ al., 2006 and Nassar, 2009). Another suggestion could be considered. These positive responses to using waste water in irrigation may be due to the increasing content of nutrients in soil irrigated with waste water. In addition, waste water irrigation may have influenced the physiological processes and enabled an increase in photosynthesis and growth (Myers et al., 1996). Also, the data revealed that tree height growth and basal area of the studied species were nearly paralleled as concluded by Klaus and Gangying (1998). The results of the three seasons revealed that using Bubblers system was the best, which gave the tallest seedlings, the wider $\mathrm{DBH}$, the greatest $\mathrm{BA}$ and the highest aboveground biomass of the three species. In addition, the enhancement effect of using Bubblers on growth parameters was followed by Drip., G.R. and SSD systems. It may be concluded that these three tropical tree species need almost to be irrigated by the highest amount of water (A1) to expand its growth parameters and biomass comparing with the lowest amount of water (A3). This may be because when the available water content in the environment gradually decreases, stomata conductance decreases substantially, reducing transpiration, but without significantly affecting photosynthesis, because stomata closure reduces the flow of water vapor more than the flow of $\mathrm{CO}_{2}$ (Kozlowski and Pallardy, 1997) resulting in reduced leaf area and growth, decreased root development and expansion, affecting plant height and canopy establishment (Martínez et al., 2002). Moreover, the present study indicated that WUE was affected significantly by the amount of wastewater treatments for the three tree species as it was always greater at the least amount of water (Fig. 4). Under this circumstance, the water distribution and wetting patterns under Bubblers and Drip are different from G.R. and SSD irrigation techniques. For G.R. and SSD systems that irrigate a relatively long wetted zone for each row plant, salt may accumulate within each zone in a pattern. In contrast, for an irrigation system employing Drip emitters or Bubblers, salt tends to accumulate mainly in the outer fringes of the wetted zone (Nimah 1985). Also, Jones (2004) and Kirnak and Demirtas (2006) revealed that drip irrigation, improves water use efficiency by decreasing runoff and evapotranspiration losses. The differential response to irrigation rates strongly suggested that the availability of soil moisture was a critical factor. The inverse value of the water use efficiency represents the amount of water applied per unit of product yield. The calculated values of this variable indicated that $0.76,1.01,1.33$ and $2.4 \mathrm{~m}^{3}$ of water were needed to produce one kilogram of dry matter yield using Bubblers, Drip., G.R., and SSD in Gmelina arborea; $0.59,0.74,0.97$, and $2.0 \mathrm{~m}^{3}$ in Khaya senegalensis $0.24,0.40,0.57$, and $0.76 \mathrm{~m}^{3}$ in Tectona grandis, respectively. This means that water savings were achieved with the Bubblers system in comparing with Drip., G.R. and SSD were $0.25,57$, and $1.64 \mathrm{~m}^{3}$ in Gmelina arborea; $0.15,0.38,1.41 \mathrm{~m}^{3}$ in Khaya 
senegalensis, $0.16,0.33$ and $0.52 \mathrm{~m}^{3}$ in Tectona grandis, respectively. The effect of wastewater amounts indicated that the contents of N, P, K, $\mathrm{Cd}, \mathrm{Pb}$ and $\mathrm{Ni}$ were the highest by using $\mathrm{A} 1$ treatment. On the contrary, the lowest contents were noticed with SSD system and A3 treatment. With respect to the effect of irrigation system on elements content, there are limited data about using wastewater irrigation by different irrigation systems. Some are focused on the accumulation of macro - and microelements. But, the results concluded that Bubblers system exceeded the other irrigation system and gave the highest nutrient $(\mathrm{N}, \mathrm{P}$ and $\mathrm{K})$ and heavy metal $(\mathrm{Cd}, \mathrm{Pb}$ and $\mathrm{Ni}$ ) contents in the leaves of the three species used, mainly if used with the highest amount of wastewater irrigation A1. Even, the heavy metal contents were in normal range, except $\mathrm{Cd}$, which was found to be higher than recommended according to Kabata and Pendias (1992).The timber trees species are mostly used for wastewater disposal and planted for wood production and non-consuming for human.

\section{Conclusion}

Water saving strategy is useful under arid regions where irrigation water is scarce, but under the conditions of this study the solely source of irrigation is wastewater. Consequently, the results of this work showed that using Bubblers system together with the application of 10.31 tree $^{-1}$ day $^{-1}$ of wastewater could be recommended in Sarabium area where water is not limiting factor to afford the highest growth parameters and biomass production of Gmelina arborea, Khaya senegalensis and Tectona grandis tree species, but greater precautions need to be taken of ground water pollution. Also, the results of this study could atribute to the Egyptian sustainable development strategy 2030, as it achieves the target of "managing the natural resources" through forestation of the desert land and the reuse of the waste water to produce woody biomass.

\section{REFERENCES}

Aiello R., Cirelli G.L. and Consoli S. (2007). Effect of reclaimed wastewater irrigation on soil and tomato fruits: A case study in Sicily (Italy). Agric. Water Manage.,93: 65-72

Allen R.G., Pereira L.S., Raes D. and Smith M. (1998). Crop evapotranspiration guidelines for computing crop water requirements. FAO Irrigation and drainage paper 56. Food and Agriculture Organization, Rome, Italy. APHA-AWWA-WEF (2005). Standard Methods for the Examination of Water and Waste water, XX ed. American Public Health Association, Washington, DC, USA.

Ayers R. S. and Westcot D.W. (1985). Water quality for agriculture. FAO, irrigation and drainage paper 29.

Bremner J. M. (1996). Nitrogen-Total. In: Sparks, D.L. (Ed.), Methods of Soil Analysis, Part 3, Chemical Methods. SSSA Book Ser: 5, Soil Science Society of America, Madison, WI, USA. pp. 1085-1122.

Chapman H. D. and Pratt P.E. (1961). Methods of Analysis for Soil and Waters. University of California, Dep. of Agric. Sci., USA. P.61.

CoStat Statistical Software (2005). Microcomputer program analysis version, 6. 4. CoHort Software, Monterey, California, USA.

ECP 501 (2005). Egyptian code of practice for the reuse of treated wastewater for agricultural purposes. The Ministry of Housing Utilities and Urban Communities. (In Arabic).

El Kateb H. and Mosandl R. (2012): Aufforstungen in ägyptischen Wüstengebieten. AFZ-Der Wald, 67(19): 36-39. In: El Kateb H., ElGindy A.G., Stimm B., Settway A.A., Zhang H., Kherashy A., Abd-Elwaheb A., Felbermeier B., Hassan H., Hassan N., Khamis S., Abd-Elbaky M., Weber M., El Hakim M. and Mosandl R. (2015). Sustainable Forestry in Desert Lands of Egypt: Information Summary. Institute of Silviculture, Technische Universität München. 36pp.

Evans R. G. and Sadler E.J. (2008). Methods and technologies to improve efficiency of water use. Water resources research, 44(7): 1-15.

Jones H.G. (2004). Irrigation Scheduling: Advantages and pitfalls of plant-based methods. J. Exp. Bot, 55: 2427-2436.

Kabata-Pendias A. and Pendias H. (1992). Trace Elements in Soils and Plants. CRC Press, Boca Raton, USA., 413 PP. 
Khan S., Cao Q., Zheng Y.M., Huang Y.Z. and Zhu Y.G. (2008). Health risks of heavy metals in contaminated soils and food crops irrigated with wastewater in Beijing, China. Environ. Pollut., 152 (3): 686-692.

Kirnak H. and Demirtas M. N. (2006). Effects of different irrigation regimes and mulches on yield and macronutrition levels of drip-irrigated cucumber under open field conditions. J. Plant Nutr., 29: 1675-1690.

Klaus V. G. and Gangying H. (1998). Modeling Forest Development. https://www.researchgate.net/publicati on/265277753_Modelling_Forest_Dev elopment

Kozlowski T.T. and Pallardy S.G. (1997). Physiology of Woody Plants. Academic Press. San Diego, USA, $411 \mathrm{pp}$.

Larchevệque M., Ballini C., Korboulewsky N. and Montes N. (2006). The use of compost in afforestation of Mediterranean areas: Effects on soil properties and young tree seedlings. Sci. Total Environ., 369 (1-3): 220-230

Mahmoud A. K. and El-Gindy A.M. (2016). Interlaced impacts of solar radiation energy and amounts of water on some forest trees growth parameters. J. Amer. Sci., 12(1): 87-95.

Martínez T., Vargas J., Muñoz A. and López J. (2002). Respuesta al déficit hídrico en Pinusleiophylla: consumo de agua y crecimiento en plántulas de diferentespoblaciones. Agrociencia, 36: 365-376.
Myers B. J., Theiveyath S. O., Brian N.O. and Bond W. J. (1996). Growth and water use of Eucalyptus grandis and Pinus radiata plantations irrigated with effluent. Tree Physiol., 1-2. 211-219.

Nassar A. (2009). Comparison of micro irrigation systems for olive trees. Misr J. Agr. Eng., 26 (1): 149- 169.

Nimah M. (1985). Localized versus drip irrigation system. Proceedings of the third drip irrigation congress, Fresno, California, USA., pp552-554.

Rusan M. J. M., Hinnawi S. and Rousan L. (2007). Long term effect of wastewater irrigation of forage crops on soil and plant quality parameters. Desalination, 215: 143-152.

Scheierling S.M., Bartone C., Mara D.D. and Drechsel P. (2010). Improving Waste water Use in Agriculture: An Emerging Priority, World Bank Policy Research Working Paper 5412.

Singh K.P., Mohan D., Sinha S. and Dalwani R. (2004). Impact assessment of treated/untreated wastewater toxicants discharged by sewage treatment plants on health agricultural and environmental quality in the waste water disposal area. Chemosphere, 55: 227-255.

Snedecor G.W. and Cochran W.G. (1980). Statistical Methods. Oxford and J.B.H. Bub com. $7^{\text {th }}$ Ed, USA.

United Nations (2014). Sustainable development goals, 15 (Life on Land). https://www.un.org/sustainabledevelop ment/biodiversity/.

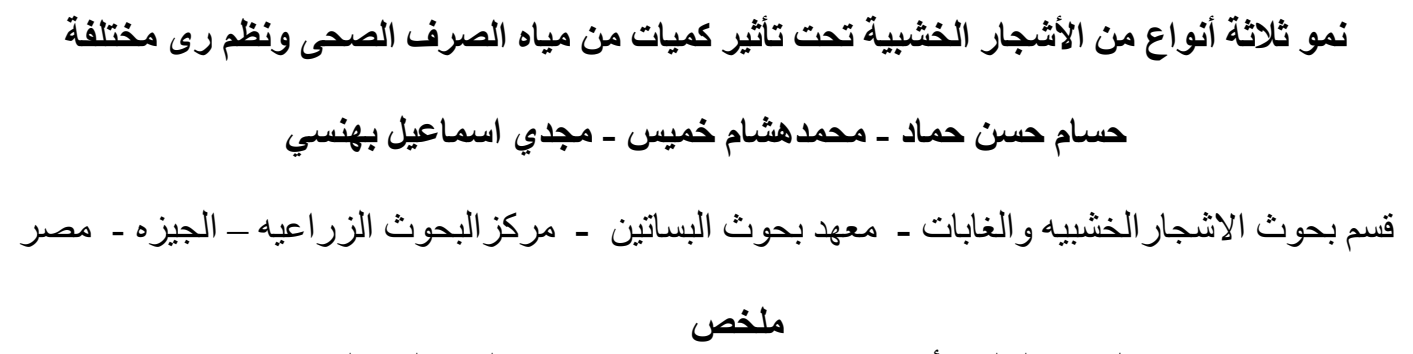

تم دراسة نمو شتلات كل من التيك الأبيض (Gmelina arborea) و الكايا السنغالى (Khaya senegalensis)

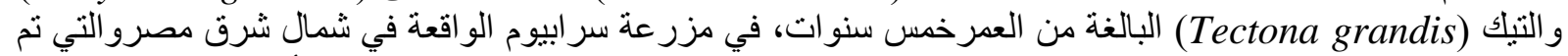

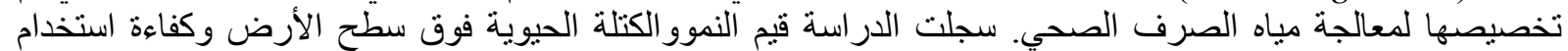
المباه ومحتوى المعادن الكبرى و المعادن ألثقبلة فى أور اق هذه الأنواع على مدار ثلاثة مو اسم (2016 و2017 و 2018). 


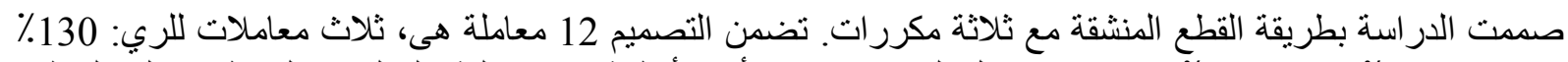

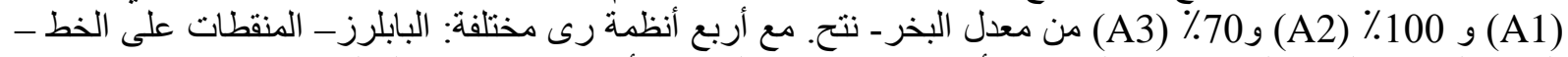

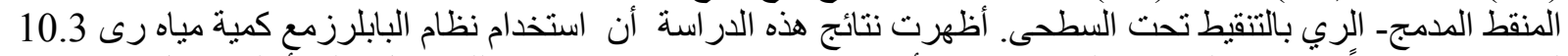

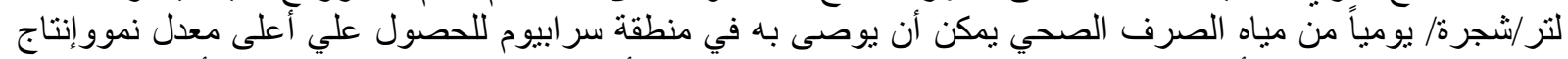

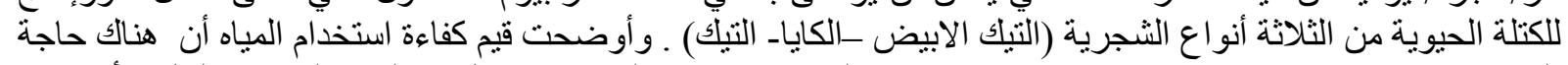

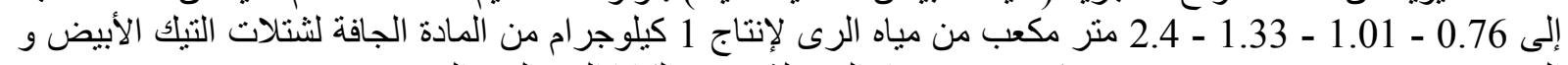

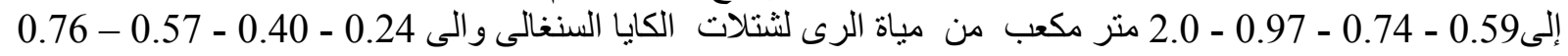

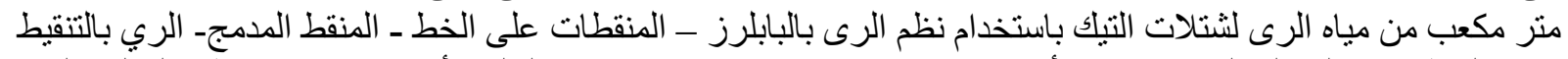

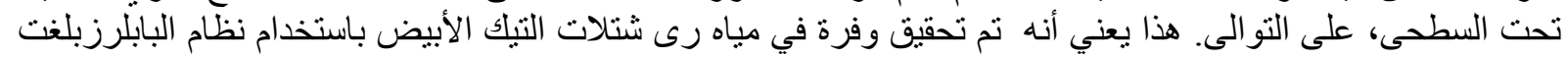

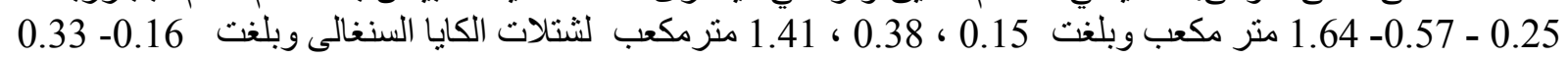

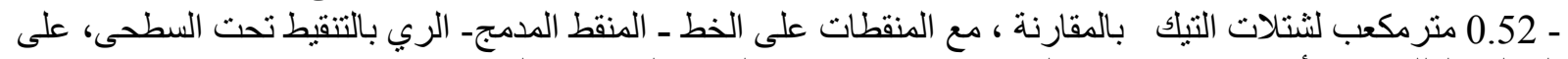

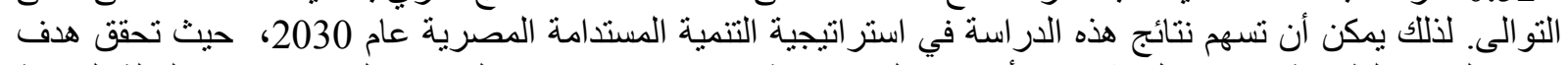

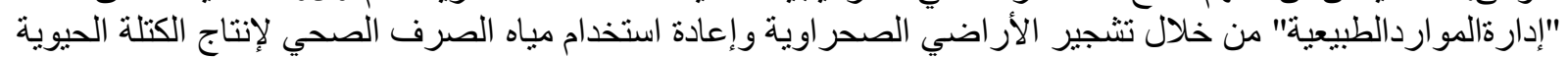

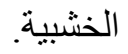
المجلة العلمية لكلية الزراعة - جامعة القاهرة - المجلا (69) العدد الرابع (أكتوبر 2018): 385-371 ـ 